\title{
EDITORIAL
}

\section{Revista História, histórias: novos rumos}

Com os artigos publicados no presente número, encerra-se o oitavo volume da RHH e têm início os trabalhos para a nova fase da revista, a ser iniciada no próximo ano. Este é, assim, o momento de endereçar nosso veemente muito obrigado a autores(as), pareceristas, conselheiros(as), assistentes executivos(as) e secretários(as) que fizeram parte da equipe, saudando o esforço despendido no trabalho de oferecer ao leitorado um material de interesse e qualidade.

A partir de 2021, a RHH adotará progressivamente novos procedimentos de trabalho, metas e paradigmas, em tudo alinhados ao objetivo permanente de fixar práticas de excelência acadêmica compatíveis com as adotadas nos melhores periódicos da área. As mudanças orientam-se sobretudo pela adesão aos critérios da ciência aberta, destinados a estabelecer metodologias mais transparentes na avaliação, uma gestão mais eficiente do fluxo de análise, bem como estratégias de difusão dos conhecimentos comunicados pelos artigos, resenhas e entrevistas que acolhemos.

A busca por sustentabilidade operacional, qualificação editorial e inserção dos materiais publicados segue sendo o compromisso que assumimos, agora ao lado de um novo conselho editorial, conselho consultivo e time de assistentes executivos, a serem incorporados a partir do próximo volume.

Boa leitura! 